\title{
HUBUNGAN KREDIBILITAS PENYULUH PERTANIAN LAPANGAN DENGAN PENERAPAN TEKNOLOGI PADA USAHATANI PADI SAWAH DI KECAMATAN PENGABUAN KABUPATEN TANJUNG JABUNG BARAT
}

\author{
Niko Firmansyah ${ }^{1}$ Rosyani ${ }^{2}$ dan Denny Denmar ${ }^{2}$
}

\begin{abstract}
1) Alumni Prodi PKP Jurusan Agribisnis Fakultas Pertanian Unja
2) Staf Pengajar Jurusan Agribisnis Fakultas Pertanian Unja

E-mail : nikofirsyah@yahoo.co.id
\end{abstract}

\begin{abstract}
ABSTRAK
Penelitian ini bertujuan (1) untuk mengetahui tingkat kredibilitas PPL di daerah penelitian , (2) untuk mengetahui tingkat penerapan teknologi pada usahatani padi sawah di daerah penelitian, (3) untuk mengetahui hubungan kredibilitas PPL dengan penerapan teknologi pada usahatani padi sawah di daerah penelitian. Penelitian ini dilaksanakan pada Tanggal 12 Februari 2014 sampai dengan 12 Maret 2014 di Kecamatan Pengabuan Kabupaten Tanjung Jabung Barat. Penelitian ini dilakukan di kecamatan Pengabuan di dua desa yaitu Desa Teluk Nilau dan Desa Mekar Jati. Pengumpulan data dalam penelitian ini terdiri dari data primer dan data sekunder. Untuk mendapatkan data yang diperoleh dilakukan wawancara dengan menggunakan kuisioner serta observasi. Hasil penelitian ini menunjukkan, bahwa tingkat kredibilitas PPL dengan penerapan teknologi pada usahatani padi sawah, tergolong tinggi yaitu (55,82 persen), tergolong sedang (30,23 persen) dan yang tergolong rendah $(13,95$ persen). Tingkat penerapan teknologi pada usahatani padi sawah tergolong tinggi $(55,82$ persen) dan tergolong rendah (44,18 persen). Adanya hubungan yang nyata antara kredibilitas PPL dengan penerapan teknologi pada usahatani padi sawah.
\end{abstract}

Kata Kunci : PPL, Usahatani Padi Sawah, Chi-Square

\section{ABSTRACT \\ THE CORRELATION CREDIBILITY OF PPL WITH THE APPLICATION OF TECHNOLOGY IN RICE FARMING AT PENGABUAN WEST TANJUNG JABUNG CITY}

The objectives of this research are: (1) to determine the level credibility of PPL in the study area, (2) to determine the level of technology implementation in rice farming in the study area, (3) to determine the correlation credibility of PPL with the application of technology in rice farming area of research. This study was conducted on February 12, until March 12, 2014 in the Pengabuan district, West Tanjung Jabung. This research was conducted in two at Pengabuan distric villages, namely Teluk Nilau village and Mekar Jati village. The data that was collected for this research consist of primary data and secondary data. To collect more precise data doing interview with quisioner and observation methods was used. Result of this research shows the level credibility of PPL with technology implementation in rice farming at the study area in general are high $(55,82$ persen), middle $(30,23$ persen) and low (13,95 persen). The level technology implementation in rice farming are high (55,82 persen) and low (44,18 persen). There are correlation between the credibility of PPL with the application of technology in rice farming rice.

Keyword: Field Extensionist Agricultural, Rice farming , Chi- square 


\section{PENDAHULUAN}

Pembangunan Pertanian memegang peranan yang sangat penting dan strategis dalam pelaksanaan Pembangunan Nasional. Komoditi tanaman pangan merupakan salah satu bagian utama dari sektor pertanian, oleh karena itu dalam upaya pengamanan komoditas tanaman pangan setiap tahunnya pemerintah selalu menempatkan tanaman pangan sebagai tanaman utama dalam setiap perencanaan pembangunan. Salah satu komoditi utama tanaman pangan adalah padi. Komoditi ini berperan sebagai pemenuh kebutuhan pokok karbohidrat masyarakat, oleh karena itu, upaya peningkatan produksi padi saat ini dan ke depan perlu difokuskan pada peningkatan produktivitas dan perubahan kondisi lahan pertanian. Salah satu upaya yang dapat dilakukan untuk mengatasi kendala tersebut, Balai Penelitian Tanaman Padi (Balitpa) dengan BPTP Jambi telah merancang suatu metode Peningkatan Produktivitas Padi Terpadu melalui penerapan teknologi pada usahatani padi sawah. Teknik-teknik produksi yang diterapkan mempertimbangkan sinergisme yang ada antara teknik tersebut agar mampu memberikan hasil yang tinggi.

Kabupaten Tanjab Barat merupakan salah satu kabupaten yang ada di Provinsi Jambi yang memiliki potensi usahatani padi sawah. Pada Tahun 2012, luas panen padi sawah di Kabupaten Tanjab Barat terbesar ketiga setelah Kabupaten Kerinci dan Kabupaten Tanjab Timur, namun produktivitas padi terendah kedua setelah Kabupaten Tanjab Timur yakni hanya mencapai 3,53 ton/ha dan 3,27 ton/ha (BPS Provinsi Jambi, 2013). Informasi dari Badan Pusat Statistik pelaksanaan program PTT hanya terdapat di 2 Kecamatan yaitu Kecamatan Batang Asam dan Kecamatan Pengabuan, sementara Kecamatan Batang Asam memiliki produktivitas yang lebih rendah dari pada Kecamatan Pengabuan. Fenomena peningkatan produktivitas pada umumnya di sebabkan oleh adanya penerapan teknologi yang lebih baik dari sebelumnya. Oleh karena itu, pemerintah daerah Tanjung Jabung Barat mengajukan Kecamatan Pengabuan menjadi sentra produksi padi sawah. Penerapan teknologi pada usahatani padi sawah di kecamatan Pengabuan telah di mulai sejak tahun 2008 dan menjadi salah satu kecamatan yang pertama kali menerapkan teknologi tersebut.

Menurut Mosher (1978), dalam mempercepat peningkatan produksi penggunaan teknologi yang berkembang merupakan syarat mutlak yang harus dipenuhi, keberhasilan produksi padi dapat tercapai lebih baik lagi jika dalam pembudidayaan padi sawah menggunakan cara yang tepat dan rutin. Usahatani padi sawah di Kecamatan Pengabuan dilakukan di satu kelurahan dan 13 desa. Peningkatan produksi maupun produktivitas dari kegiatan berusahatani tidak terlepas dari pengalaman, kebiasaan dan modal petani, kepiawaian seorang petani di dalam mengelola usahatani baik dari pengolahan lahan sampai dengan pasca panen. Selain itu peran PPL juga yang tidak kalah pentingnya untuk meningkatkan produktivitas usaha tani. Keberhasilan penyuluh pertanian dipengaruhi oleh banyak variabel, salah satunya adalah kredibilitas penyampai pesan. Pesan yang bersumber dari pihak yang memiliki kredibilitas tinggi pada umumnya lebih mudah mempengaruhi penerima pesan. Menurut De Vito (1997) kredibilitas memiliki tiga dimensi penting yaitu kompetensi, karakter, karisma.

Berdasarkan uraian penulis tertarik untuk melakukan penelitian dengan judul Hubungan Kredibilitas Penyuluh Pertanian Lapangan dengan Penerapan Teknologi Pada Usahatani Padi Sawah di Kecamatan Pengabuan Kabupaten Tanjung Jabung Barat. Berdasarkan uraian-uraian tersebut kajian tentang kredibilitas PPL dengan penerapan teknologi pada usahatani padi sawah, menurut penulis perlu dikaji. Hipotesis dari penelitian ini, diduga terdapat hubungan antara kredibilitas PPL dengan penerapan teknologi pada usahatani padi sawah di Kecamatan Pengabuan Kabupaten Tanjung Jabung Barat. Penelitian bertujuan untuk mengetahui tingkat kredibilitas PPL, untuk mengetahui tingkat penerapan teknologi pada usahatani padi sawah, dan untuk mengetahui hubungan kredibilitas PPL dengan penerapan teknologi pada usahatani padi sawah. 


\section{METODE PENELITIAN}

Penelitian ini dilaksanakan di Kecamatan Pangabuan Kabupaten Tanjung Jabung Barat. Pelaksanaan penelitian ini dilakukan sejak bulan Februari sampai dengan Maret 2014, Pemilihan lokasi ini sebagai tempat penelitian dengan pertimbangan bahwa Kecamatan Pengabuan merupakan pengembangan usaha tani padi sawah. Penentuan Kecamatan dilakukan secara sengaja (pourposive) dengan pertimbangan bahwa Kecamatan Pengabuan mempunyai lahan panen terluas dibandingkan Kecamatan lainnya. Berdasarkan data (BPS) Tahun 2013 Kecamatan Pengabuan merupakan salah satu Kecamatan dengan produktivitas tertinggi. Penelitian ini dilaksanakan di Desa Teluk Nilau dan Desa Mekar Jati Kecamatan Pengabuan Kabupaten Tanjung Jabung Barat. Jumlah kelompok tani terbanyak dan jumlah petani tertinggi. Desa Teluk Nilau terdapat sebanyak 955 KK dan 434 KK di Desa Mekar Jati yang mengusahakan usaha tani padi sawah. Adapun objek penelitian ini adalah petani yang mengusahakan usaha tani padi sawah dengan menerapkan teknologi pada usahatani padi sawah. Ruang lingkup penelitian ini yaitu untuk melihat kredibilitas PPL dengan penerapan teknologi pada usahatani padi sawah di Kecamatan Pengabuan Kabupaten Tanjung Jabung Barat.

Penarikan sampel dilakukan dengan cara pourposive (sengaja) karena didaerah penelitian memiliki trasportasi darat yang sulit dilalui dan luas wilayah penelitian yang tidak memungkinkan untuk dilakukan dengan cara simple ramdom sampling. Daftar nama populasi didapat dari PPL dan ketua GAPOKTAN, sehingga jumlah populasi keseluruhan dari kedua desa tersebut adalah $1389 \mathrm{KK}$ dengan batas toleransi $15 \%$. Jadi jumlah sampel yang di ambil dari populasi tersebut sebanyak 43 sampel ditentukan sesuai dengan metode Slovin.

\section{Metode Analisis Data}

Data yang diperoleh dari hasil penelitian akan disederhanakan dengan menggunakan tabulasi, kemudian dianalisis secara deskriptif melalui scoring dan persentase. Scoring digunakan untuk mengkuantitatifkan data kualitatif, hal ini dilakukan untuk mengetahui kredibilitas PPL terhadap penerapan teknologi pada usahatani padi sawah.

Untuk mengetahui hubungan antara kredibilitas PPL dengan penerapan teknologi pada usahatani padi sawah digunakan analisis statistik non parametrik melalui Uji Chi-Square (Siegel, 1997)

$$
\chi^{2}=\sum_{1}^{r} \sum_{i=1}^{k} \frac{(0 \mathrm{ij}-E i j) 2}{E i j}
$$

Dimana Oij $=$ jumlah observasi untuk kasus- kasus yang dikategorikan dalam baris ke-i pada kolom ke-j kolom ke-j

Eij = banyak kasus yang diharapkan dibawah HO untuk dikategorikan dalam baris ke-i pada

Menurut Bahri (2005), yaitu : dengan uji Chi-Square yang kontingenya $2 \times 3$ menggunakan rumus sebagai berikut:

$$
\chi^{2} h i t=\frac{N_{A}}{N}\left\{\frac{a_{11}{ }^{2}}{C_{A}}+\frac{a_{12}{ }^{2}}{C_{B}}+\frac{a_{13}{ }^{2}}{C_{C}}\right\}+\frac{N_{B}}{N}\left\{\frac{a_{21}{ }^{2}}{C_{A}}+\frac{a_{22}{ }^{2}}{C_{B}}+\frac{a_{23}{ }^{2}}{C_{C}}\right\}
$$

Tabel 1 Kontingensi

\begin{tabular}{ccccc}
\hline \multirow{2}{*}{ Penerapan teknologi } & \multicolumn{3}{c}{ Kredibilitas PPL } & \multirow{2}{*}{ Jumlah } \\
\cline { 2 - 4 } & Tinggi & Sedang & Rendah & \\
\hline Tinggi & $a_{11}$ & $a_{12}$ & $a_{13}$ & $N_{A}$ \\
Rendah & $a_{21}$ & $a_{22}$ & $a_{23}$ & $N_{B}$ \\
\hline Jumlah & $C_{A}$ & $C_{B}$ & $C_{C}$ & $N$ \\
\hline
\end{tabular}


Nilai $\left(\chi^{2}\right)$ pada tabel derajat bebas $(\mathrm{Db})=1$ Pada tingkat kepercayaan $95 \%$ adalah 5,99. dapat di bandingkan antara $\chi^{2}$ hitung dengan $\chi^{2}$ tabel dengan keputusan sebagai berikut :

1. Jika $\chi^{2}$ hitung [ $\left(\chi^{2} \leq \chi^{2} \alpha=5 \% \mathrm{db}=(\mathrm{b}-1)(\mathrm{k}-1)\right.$ ] terima Ho

2. Jika $\chi^{2}$ hitung $\left[\left(\chi^{2}>\chi^{2} \alpha=5 \% \mathrm{db}=(\mathrm{b}-1)(\mathrm{k}-1)\right]\right.$ tolak Ho

Dimana:

$H_{0}=$ Perbedaan kredibilitas PPL tidak menyebabkan perbedaan penerapan teknologi pada usahatani padi sawah di Kecamatan Pengabuan

$H_{1}=$ Perbedaan kredibilitas PPL menyebabkan perbedaan penerapan teknologi pada usahatani padi sawah di Kecamatan Pengabuan, Selanjutnya untuk mengukur derajat hubungan antara kedua variabel di gunakan koefisien kontingensi dengan rumus sebagai berikut. $C_{h i t}=\sqrt{\frac{\chi^{2}}{\chi^{2}+N}}$

Dimana :

$\chi^{2}=\chi^{2}$ hitung nilai Chi-Square

$\mathrm{N}=$ Jumlah sampel

$\mathrm{C}=$ Koefisien Kontingensi , nilai ini teletak antara $0-0,707$

Selanjutnya Untuk Mengukur keeratan hubungan digunakan formulasi :

$$
\begin{gathered}
r=\frac{C_{\text {hit }}}{C_{\text {maks }}} \quad C_{\text {max }}=\sqrt{\frac{m-1}{m}} \\
r=\frac{\sqrt{\frac{\chi^{2}}{\chi^{2}+N}}}{\sqrt{\frac{m-1}{m}}} \\
C_{\text {max }}=\sqrt{\frac{3-1}{3}}=\sqrt{\frac{2}{3}}=0,8164
\end{gathered}
$$

Keterangan :

$r=$ Koefisien keeratan hubungan

$\chi^{2}=$ Nilai uji Chi-Square

$\mathrm{N} \quad=$ Jumlah sampel

$\mathrm{m} \quad=$ Jumlah kolom/baris pada tabulasi silang

Dengan kategori :

a. Hubungan digolongkan lemah apabila nilai terletak antara $0-0,272$

b. Hubungan digolongkan cukup kuat apabila nilai terletak antara 0,273-0,408

c. Hubungan digolongka $n$ kuat apabila nilai terletak antara 0,409-0,816

Selanjutnya untuk melihat adanya hubungan atau tidak maka di gunakan formulasi yakni :

$$
\begin{array}{ll}
\mathrm{t}_{\text {hit }}=\sqrt{\frac{N-2}{1-(r)^{2}}} \quad \text { dimana: } \\
\mathrm{HO} ; \mathrm{r}=0 \quad \mathrm{H}_{1} ; \mathrm{r} \neq 0
\end{array}
$$

Jika t hitung $(\leq \mathrm{t}$ tabel $=(\alpha=5 \% \mathrm{db}=\mathrm{N}-2)\}$ Terima Ho

Jika t hitung ( $>$ t tabel $=(\alpha=5 \% \mathrm{db}=\mathrm{N}-2)\}$ Tolak Ho Dimana :

$H_{0}=$ Tidak terdapat hubungan yang nyata antara kredibilitas PPL terhadap tingkat penerapan teknologi pada usahatani padi sawah di Kecamatan Pengabuan

$H_{1}=\quad$ Terdapat hubungan yang nyata antara kredibilitas PPL terhadap tingkat penerapan teknologi pada usahatani padi sawah di Kecamatan Pengabuan. 


\section{HASIL DAN PEMBAHASAN}

\section{Kredibilitas PPL dengan Penerapan Teknologi pada Usaha tani Padi Sawah}

Penyuluh Pertanian Lapangan adalah orang yang berperan dalam merubah perilaku petani kea rah yang lebih baik. Peran ini dapat berhasil dengan baik manakala terjadi interaksi dan komunikasi yang lebih baik pula antara PPL dengan petani. Melalui interaksi dan komunikasi itu, kredibilitas PPL akan teruji. PPL yang memiliki kredibilitas tinggi akan mampu merubah perilaku dari petani yang akhirnya akan meningkatkan penerapan teknologi oleh petani dan demikian pula sebaliknya. Kredibilitas memiliki tiga komponen yaitu kompetensi, karakter dan kharisma. Dalam penelitian ini, ketiga komponen kredibilitas tersebut telah di uji keterhubungannya dengan penerapan teknologi pada Usaha tani Padi Sawah di Kecamatan Pengabuan.

Teknologi yang dimaksud dalam penelitian ini adalah penerapan teknologi pada usahatani padi sawah merupakan suatu perangkat pendekatan yang akan mengembalikan tingkat hasil panen padi seperti sediakala atau bahkan akan meningkat dari sebelumnya. Disamping itu, teknologi ini juga akan menghasilkan gabah yang bermutu sehingga akan menghasilkan beras yang berlualitas. Sebab, penggunaan teknologi ini tepat untuk lokasi dilahan yang irigasi teknis dengan tujuan akan menjaga kelestarian lingkungan tumbuh padi serta ramah lingkungan.

Kredibilitas PPL dalam penerapan teknologi pada usaha tani padi sawah memiliki frekuensi dan persentase untuk lebih jelas dapat dilihat pada tabel berikut :

Tabel 2. Distribusi frekuensi Kredibilitas PPL dengan Penerapan Teknologi pada Usahatani Padi Sawah di Kecamatan Pengabuan Kabupaten Tanjung Jabung Barat Tahun 2014

\begin{tabular}{|c|c|c|c|}
\hline Skor & Kategori & Frekuensi & Persentase (\%) \\
\hline $96-130$ & Tinggi & 24 & 55,82 \\
\hline $61-95$ & Sedang & 13 & 30,23 \\
\hline $26-60$ & Rendah & 6 & 13,95 \\
\hline \multicolumn{2}{|c|}{ Jumlah } & 43 & 100 \\
\hline
\end{tabular}

Sumber : Hasil Olahan Data Kuisioner Tahun 2014

Hasil dari Tabel 2 menjelaskan bahwa kredibilitas PPL dalam penerapan teknologi pada usaha tani padi sawah cendrung tinggi sebesar 55, 82 persen. Hal ini jika ketiga unsur kredibilitas digabungkan. Jika unsur kredibilitas PPL itu dipisah atau tidak di kategorikan menurut tinggi, sedang rendah, di ketahui ternyata kredibilitas PPL cendrung pada komponen kompetensi karena 75,05 \% kredibilitas PPL berada pada komponen ini. Untuk lebih rincinya dapat dilihat pada Tabel 3

Tabel 3. Kecendrungan Kredibilitas PPL dengan Penerapan Teknologi pada Usahatani Padi Sawah di Kecamatan Pengabuan Kabupaten Tanjung Jabung Barat Tahun 2014

\begin{tabular}{lc}
\hline Indikator Kredibilitas PPL & Persentase Capaian (\%) \\
\hline Kompetensi & 75,05 \\
Karakter & 71,51 \\
Kharisma & 67,71 \\
\hline
\end{tabular}

Sumber : Hasil Olahan Data Kuisioner Tahun 2014

Hasil dari Tabel 3 menjelaskan bahwa persentase capaian kredibilitas PPL tertinggi terletak pada kompetensi dengan persentase 75,05 \%. Dengan begitu bahwa kompetensi PPL yang mendominasi petani untuk meningkatkan hasil produksi usaha taninya dan menerapkan teknologi-teknologi baru.

\section{Kredibilitas PPL Berdasarkan Kompetensi}

Kompetensi artinya seberapa banyak atau jumlah pengetahuan PPL mengetahui persis persoalannya tentang bahan atau isi pesan yang akan disampaikan akan mempengaruhi pesannya. Sehingga komunikasi berlangsung efektif dan khalayak dapat paham dan mengerti. PPL berperan sebagai pendidik yaitu memberikan pengetahuan atau cara-cara dalam budidaya tanaman, agar para petani lebih terarah dalam usahataninya, meningkat hasil dan mengatasi kegagalan-kegagalan dalam 
usahataninya. Kredibilitas PPL berdasarkan kompetensi dalam penerapan teknologi pada usahatani padi sawah memiliki frekuensi dan persentase untuk lebih jelas dapat dilihat pada Tabel 4

Tabel 4. Skor Kredibilitas PPL Berdasarkan Kompetensi dengan Penerapan Teknologi pada Usahatani Padi Sawah di Kecamatan Pengabuan 2014

\begin{tabular}{cccc}
\hline Skor & Kategori & Frekuensi & Persentase (\%) \\
\hline $41-55$ & Tinggi & 25 & 58,1 \\
$26-40$ & Sedang & 11 & 25,6 \\
$11-25$ & Rendah & 7 & 16,3 \\
\hline \multicolumn{2}{r}{ Jumlah } & $\mathbf{4 3}$ & $\mathbf{1 0 0}$ \\
\hline
\end{tabular}

Sumber : Hasil Olahan Data Kuisioner Tahun 2014

Tabel 4 menjelaskan bahwa kredibilitas PPL berdasarkan kompetensi cendrung berada pada kategori tinggi 58,1 persen dari jumlah sampel.

\section{Kredibilitas PPL Berdasarkan Karakter}

Karakter artinya sikap sumber atau PPL perlu mempunyai sikap positif memiliki kejujuran dan sifat-sifat hakiki seseorang, yaitu harus yakin ketika melakukan penyuluhan kepada petani PPL memiliki bahan yang berupa materi dan fakta yang bernilai berita, sehingga isi pesan yang dikomunikasikan atau disampaikannya kepada petani berlangsung secara efektif. Kredibilitas PPL berdasarkan karakter dalam penerapan teknologi pada usahatani padi sawah memiliki frekuensi dan persentase untuk lebih jelas dapat dilihat pada Tabel 5

Tabel 5. Skor Kredibilitas PPL Berdasarkan Karakter dengan Penerapan Teknologi pada Usahatani Padi Sawah di Kecamatan Pengabuan 2014

\begin{tabular}{|c|c|c|c|}
\hline Skor & Kategori & Frekuensi & Persentase (\%) \\
\hline $30-40$ & Tinggi & 23 & 53,5 \\
\hline $19-29$ & Sedang & 14 & 32,6 \\
\hline $8-18$ & Rendah & 6 & 13,9 \\
\hline \multicolumn{2}{|c|}{ Jumlah } & 43 & 100 \\
\hline
\end{tabular}

Sumber : Hasil Olahan Data Kuisioner Tahun 2014

Tabel 5 dapat menjelaskan bahwa kredibilitas PPL berdasarkan karakter cendrung berada pada kategori tinggi sebesar 53,5 persen dari jumlah sampel.

\section{Kredibilitas PPL Berdasarkan Kharisma}

Didaerah penelitian telah dilakukan suatu tehnik bercocok tanam yang baru melalui penerapan teknologi pada usahatani padi sawah. Diperkirakan faktor keterampilan berkomunikasi adalah salah satu faktor yang mendukung penerapan teknologi pada usahatani padi sawah didaerah penelitian tersebut. Kredibilitas PPL berdasarkan karakter dalam penerapan teknologi pada usahatani padi sawah memiliki frekuensi dan persentase untuk lebih jelas dapat dilihat pada Tabel 6

Tabel 6. Skor Kredibilitas PPL Berdasarkan Kharisma dengan Penerapan Teknologi pada Usahatani Padi Sawah di Kecamatan Pengabuan 2014

\begin{tabular}{cccc}
\hline Skor & Kategori & Frekuensi & Persentase (\%) \\
\hline $26-35$ & Tinggi & 19 & 44,1 \\
$16-25$ & Sedang & 17 & 39,6 \\
$7-15$ & Rendah & 7 & 16,3 \\
\hline Jumlah & & $\mathbf{4 3}$ & $\mathbf{1 0 0}$
\end{tabular}

Sumber : Hasil Olahan Data Kuisioner Tahun 2014

Tabel 6 menjelaskan bahwa kredibilitas PPL berdasarkan kharisma cendrung berada pada kategori tinggi dengan persentase sebesar 44,1 persen dari jumlah sampel. 


\section{Penerapan Teknologi pada Usahatani Padi Sawah}

Penerapan inovasi merupakan salah satu hal utama bagi petani untuk meningkatkan produksi usahatani terutama pada komoditas padi. Inovasi yang dimaksud dalam penelitian ini adalah penerapan teknologi pada usaha tani padi sawah. Penerapan teknologi pada usaha tani padi sawah merupakan pendekatan dalam budidaya tanaman dan berperan penting dalam meningkatkan produksi padi sawah dalam beberapa tahun terakhir ini. Teknologi ini merupakan suatu pendekatan inovatif dan dinamis yang bertujuan untuk meningkatkan produksi dan pendapatan petani melalui beberapa komponen.

Berdasarkan hasil wawancara dengan kepala BP3K dan PPL bahwa pelaksanaan teknologi di Kecamatan Pengabuan Kabupaten Tanjung Jabung Barat melalui pendekatan ini diperkenalkan pada tahun 2008 oleh BPTP Propinsi Jambi. Program ini pertama kali di laksanakan di Desa Teluk Nilau kemudian di lanjutkan di Desa Mekar Jati. Awal mulanya, pengujian teknologi ini oleh BPTP dengan turun langsung kelapangan dengan membuat petakan atau plot sebagai percontohan ditempat yang strategis dengan tujuan agar petani dapat melihat secara langsung bagaimana keunggulan dan manfaat dari sistem teknologi ini. Dengan dibuatnya suatu percontohan, maka petani sekarang mampu menerapkan sistem yang telah di sosialisasikan. Di lahan irigasi memang sangat cocok untuk diterapkan paket sistem yaitu penerapan teknologi pada usaha tani padi sawah. Hal ini, mengindikasikan bahwa petani di Kecamatan Pengabuan merespon sangat baik dengan sistem teknologi ini. Berikut ini adalah gambaran pelaksanaan sistem teknologi pada usahatani padi sawah responden yang disajikan pada Tabel 7.

Tabel 7. Distribusi Frekuensi Responden Berdasarkan Klasifikasi Penerapan Teknologi pada Usahatani Padi Sawah di Kecamatan Pengabuan Kabupaten Tanjung Jabung Barat Tahun 2014

\begin{tabular}{lc}
\hline Indikator & Persentase (\%) \\
\hline Varietas Unggul & 87 \\
Benih Bermutu & 70,7 \\
Pengolahan Tanah & 68,1 \\
Persemaian & 60,9 \\
Bibit & 77 \\
Penanaman & 71 \\
Pemupukan & 65 \\
Pengairan & 67 \\
Pengendalaian Hama dan Penyakit & 65 \\
Pengendalian Gulma & 72,6 \\
Panen dan Pasca Panen & 77,2 \\
\hline
\end{tabular}

Sumber : Hasil Olahan Data Kuisioner Tahun 2014

Hasil dari Tabel 7 menjelaskan bahwa dari 11 komponen penerapan teknologi pada usaha tani padi sawah persentase tertinggi terdapat pada pengetahuan dan penerapan terhadap varietas unggul dengan persentase sebesar $87 \%$, penerapan tertinggi terdapat pada penggunaan varietas unggul di karenakan masyarakat di daerah penelitian sudah mengetahui kelebihan dan kekurangan dari varietas ciherang yang menjadi anjuran. sedangkan penerapan terendah terdapat pada persemaian 60,9\%, di mana masyarakat atau petani sampel di daerah penelitian melakukan penyemaiaan dengan cara mereka sendiri tidak mengikuti anjuran yang di berikan oleh program dengan kriteria luas persemaian adalah $4 \%$ dari luas pertanaman ( $250 \mathrm{~m} 2 /$ Ha lahan).

Lahan persemaian dipupuk dengan urea sebanyak $10 \%$ dari total urea yang digunakan (20-40 g urea/m2). Lahan persemaian juga perlu diberi pupuk kompos yang dicampur dengan sekam atau serbuk gergaji kayu (abu) dengan takaran $2-4 \mathrm{Kg} / \mathrm{m} 2$ untuk memudahkan pencabutan bibit terutama bibit muda. Berikut adalah skor penerapan teknologi pada usaha tani padi sawah. 
Tabel 8. Skor Penerapan Teknologi pada Usahatani Padi Sawah di Kecamatan Pengabuan Kabupaten Tanjung Jabung Barat Tahun 2014

\begin{tabular}{cccc}
\hline Kategori & Skor & Frekuensi & Persentase (\%) \\
\hline Tinggi & $107-160$ & 24 & 55,82 \\
Rendah & $52-106$ & 19 & 44,18 \\
\hline & Jumlah & 43 & 100 \\
\hline
\end{tabular}

Sumber : Hasil Olahan Data Kuisioner Tahun 2014

Hasil dari Tabel 8 menjelaskan bahwa 55,82 persen tingkat penerapan teknologi pada usaha tani padi sawah berada pada kategori tinggi. Artinya mengindikasikan bahwa sebagian besar petani di daerah penelitian telah mengenali spenerapan teknologi pada usaha tani padi sawah sesuai anjuran.

Berdasarkan tabel tersebut terdapat beberapa komponen dari teknologi yang telah diterapkan masih relatif rendah. Sehubungan hal tersebut, perlu adanya pendampingan dari pemerintah dan PPL agar masing-masing komponen yang masih relatif rendah tersebut bisa dievaluasi. Menurut Morissan (2010), dalam kurva difusi inovasi menjelaskan bahwa golongan laggard (kelompok tertinggal) merupakan kelompok masyarakat yang paling akhir menerima inovasi. Kelompok tertinggal ini masih terikat pada masa lalu yaitu pada cara tradisional dalam melakukan sesuatu dan mereka enggan untuk melakukan sesuatu yang baru. Dalam kurvanya juga menjelaskan bahwa golongan ini mempunyai nilai $16 \%$ dalam adopsi inovasi.

Dari $16 \%$ nilai golangan laggard dalam adopsi inovasi maka sistem pelaksanaan teknologi yang perlu peningkatan dan pendampingan dari pemerintah atau PPL meliputi benih bermutu, persemaian, pemupukan, dan pengendalian hama dan penyakit. Sedangkan komponen teknologi yang perlu ditingkatkan agar terjadi kesetabilan dalam pencapaian produksi pada usahatani padi sawah adalah varietas unggul, pengolahan tanah, bibit, penanaman, pengairan, pengendalian gulma dan penangan panen dan pascapanen. Untuk lebih jelasnya gambaran mengenai pencapaian sistem pelaksanaan teknologi dalam usahatani padi sawah dapat dilihat pada lampiran 15. Kerja keras dari usaha yang telah dicapainya saat ini, terbukti meningkatkan hasil produksi sehingga untuk pemenuhan kebutuhan hidupnya petani mampu menggantungkan hidupnya pada sekor pertanian.

Selain itu, sistem teknologi ini dapat mengembalikan produksi juga memperbaiki taraf kehidupan yang mereka rasakan. Namun, itu semua tidak terlepas dari kredibilitas PPL dalam memperkenalkan teknologi pada usaha tani padi sawah dan petani yang menerapkannya hingga sekarang.

\section{Hubungan Kredibilitas PPL dengan Penerapan Teknologi pada Usahatani Padi Sawah.}

Kredibilitas PPL dengan penerapan teknologi pada usahatani padi sawah merupakan keberhasilan usaha - usaha PPL penyuluh yang tidak terlepas dari tingkat komunikasi antara PPL dengan para petani. Analisis hubungan antara aspek kredibilitas PPL dengan penerapan teknologi pada usaha tani padi sawah dijelaskan pada uraian berikut ini :

Tabel 9. Kontingensi Kredibilitas PPL dengan Penerapan Teknologi pada Usahatani Padi Sawah di Kecamatan Pengabuan 2014

\begin{tabular}{ccccc}
\hline \multirow{2}{*}{$\begin{array}{c}\text { Teknologi } \\
\text { usahatani }\end{array}$} & \multicolumn{3}{c}{ Kredibilitas PPL } & Jumlah \\
\cline { 2 - 4 } & Tinggi & Sedang & Rendah & \\
\hline Tinggi & 17 & 8 & 4 & 29 \\
\hline Rendah & 7 & 5 & 2 & 14 \\
\hline Jumlah & $\mathbf{2 4}$ & $\mathbf{1 3}$ & $\mathbf{6}$ & $\mathbf{4 3}$ \\
\hline
\end{tabular}

Sumber : Hasil Olahan Data Kuisioner Tahun 2014 
Berdasarkan uji statistik non parametrik dengan menggunakan uji Chi-square di peroleh nilai $X^{2}$ hit $=14,75$ dengan nilai $X^{2}$ tabel $(\alpha=5 \% \mathrm{db}=2)=5,99$. Karena $X^{2}$ hit $=14,75>X^{2}$ tabel $(\alpha=5 \%$ $\mathrm{db}=2)=5,99$ maka diputuskan tolak $H_{0}$ (terima $H_{1}$ ), yang berarti tinggi rendahnya kredibilitas PPL mempengaruhi tinggi rendahnya penerapan teknologi pada usaha tani padi sawah di Kecamatan Pengabuan. Derajat kontingensi kredibilitas PPL dengan penerapan teknologi pada usaha tani padi sawah adalah $C_{\text {hit }}=0,5053$ dan $C_{\text {maks }}=0,8164$. Hal ini artinya derajat kecendrungan kredibilitas PPL menyebabkan perbedaan penerapan teknologi pada usaha tani padi sawah adalah 50,53 persen.

Kecendrungan hubungan antara kredibilitas PPL dengan penerapan teknologi pada usaha tani padi sawah tergolong kuat dimana nilai $C=0,5053$ (berada antara 0,4082 - 0,8164). Sedangkan pengukuran derajat korelasi antara perbedaan kredibilitas PPL dengan penerapan teknologi pada usaha tani padi sawah diperoleh $r=0,6189$. Hasil pengujian terhadap koefisien $r$ diperoleh $T_{\text {hit }}=5,045$. Karena $T_{\text {hit }}=5,045 T_{\text {tabel }}(\alpha / 2=5 \% \mathrm{db}=41)=2,021$ maka tolak $H_{0}$ (terima $H_{1}$ ) artinya perbedaan kredibilitas PPL berhubungan nyata dengan penerapan teknologi pada usaha tani padi sawah di Kecamatan Pengabuan.

Dari hasil tiga analisis seperti pada Tabel 9 memperlihatkan hubungan kredibilitas PPL dengan penerapan teknologi pada usahatani padi sawah didaerah penelitian, yaitu ada kecendrungan jika kredibilitas PPL nya tinggi maka tingkat penerapan teknologi pada usahatani padi sawah tinggi juga, hal ini memperlihatkan bahwa semakin tinggi kredibilitas PPL maka semakin tinggi pula keinginan seseorang untuk menerapkan suatu teknologi. Kredibilitas sumber dapat didefinisikan sebagai keahlian dan kemampuan dapat dipercaya yang dimiliki sumber, untuk itu seorang PPL harus memiliki kredibilitas yang tinggi agar model pendekatan yang akan disampaikan dapat di terima oleh para petani dalam meningkatan produktivitas usaha tani tersebut (Sutisna, 2001). Ditambahkan dengan Hernanto (2000) mengatakan keberhasilan usaha- usaha PPL pada dasarnya sangat ditentukan oleh tingkat komunikasi antara PPL dengan para petani.

\section{KESIMPULAN}

Bersadarkan hasil penelitian di lapangan maka dapat diambil beberapa kesimpulan sebagai berikut tingkat kredibilitas PPL di Kecamatan Pengabuan Kabupaten Tanjung Jabung Barat dalam melaksanakan penerapan teknologi pada usahatani padi sawah tergolong tinggi dengan hasil persentase 55,82 persen. Dari 3 (tiga) komponen kredibilitas, masing - masing memiliki persentase yaitu kompetensi 75,05 persen, karakter 71,51 persen, dan kharisma 67,71 persen. Tingkat penerapan teknologi pada usahatani padi sawah tergolong tinggi, dari 11 komponen tingkat penerapan teknologi pada usaha tani padi sawah tertinggi terdapat pada penggunaan varietas unggul yaitu varietas chierang 87 persen dan terendah terdapat pada persemaian 60,9 persen. Adanya hubungan yang nyata antara kredibilitas PPL dengan penerapan teknologi pada usahatani padi sawah di Kecamatan Pengabuan Kabupaten Tanjung Jabung Barat.

\section{UCAPAN TERIMA KASIH}

Ucapan terima kasih di sampaikan kepada ibu Dr. Ir. Hj. Rosyani, MS selaku pembimbing skripsi pertama, bapak Dr. Ir. Denny Denmar, MP selaku pembimbing skripsi kedua, ibu Yulismi S.P., M.Si selaku dosen pembimbing akademik, bapak Lurah Teluk Nilau dan bapak kepala Desa Mekar Jati yang telah memberikan izin kepada saya untuk melakukan penelitian di Kecamatan Pengabuan Kabupaten Tanjung Jabung Barat, bapak Sumardi dan Surdi selaku PPL di Kelurahan Teluk Nilau dan Desa Mekar Jati yang telah membantu dalam penelitian ini. 


\section{DAFTAR PUSTAKA}

Badan Pusat Statistik. 2013. Luas Panen- Produktivitas- Produksi Tanaman Padi Seluruh Provinsi Tahun 2012. http://www.bps.go.id (diakses pada 23 Januari 2013).

Dinas Tanaman Pangan dan Hortikultura Kabupaten Tanjung Jabung Barat. 2011. Tanjab Barat Dalam Angka 2011.BPS Jambi 2011..

Devito, Joseph. 1997. Komunikasi Antar Manusia. Jakarta : Professional Book

Hernanto, Fadoli. 2000. Ilmu Usahatani. Penebar Swadaya. Jakarta.

Morissan, Andy Corry Wardhani dan Farid Hamid. 2010. Teori Komunikasi Massa. Ghalia Indonesia. Bogor.

Mosher, Arthur, 1991. Menggerakkan Dan Membangun Pertanian. Jakarta : Yasaguna.

Siegel, Sidney. 1992. Statistik Nonparametrik Untuk Ilmu-Imu Sosial. Gramedia. Jakarta.

Sutisna. 2001, Perilaku Konsumen dan Komunikasi Pemasaran, Penerbit PT. Remaja Rosdakarya, Bandung, Cetakan I. 